\title{
A Palimpsestic Reading of Female Identity in Chimamanda Adichie's Purple Hibiscus
}

\author{
Peace Sorochi Longdet \\ Department of English, School of Languages, Federal College of Education, Pankshin, Nigeria
}

\author{
Email address: \\ peacelongdet2011@gmail.com
}

\section{To cite this article:}

Peace Sorochi Longdet. A Palimpsestic Reading of Female Identity in Chimamanda Adichie's Purple Hibiscus. English Language, Literature \& Culture. Vol. 5, No. 2, 2020, pp. 53-59. doi: 10.11648/j.ellc.20200502.11

Received: March 1, 2020; Accepted: March 17, 2020; Published: April 7, 2020

\begin{abstract}
This study examines female identity in the novel of Chimamanda N. Adichie using an eclectic model that combines African feminist theory and palimpsestic analogy. A critical reading of the text reveals that African women writers have a strong commitment towards the redefinition of female identity in literary texts. In terms of the major preoccupation of female writers in their works, it has been observed that Adichie is passionate about her projection of strong female characters alongside weak female characters that function under the traditional atmosphere. Adichie creates female characters that on the surface appear docile, timid, robot-like and passive, however through her dexterous master - craft she proceeds to deconstruct, such portraiture to allow the creation of another identity on the erased surface. This style, gives the female characters a multi-layered pattern similar to that of an erased writing on a piece of parchment-palimpsest. I argue that through this palimpsestic portraiture, Adichie advocates for other means of female assertion- education is a strong weapon for her female characters' self-assertion and empowerment. The study, therefore, suggests that for objective reading and interpretation of Purple Hibiscus particularly as it relates to female characters critics should negotiate the ability to look at women's work with fresher eye.
\end{abstract}

Keywords: Palimpsest, Female Identity, Gender, Oppressive System Africa

\section{Introduction}

African women writers are aware of their society's unique history, tradition and ethical values. They interpret their unique experiences in their works in order to create a link between what was history and what they set to create through their writing in the present with a commitment to changing the perception of womanhood. Therefore, their commitment to creating a new perception of the African woman leads them to use the family unit as, a pointer. This awareness provides the backdrop for the study of the nature of female identity in Adichie's Purple Hibiscus and also for the investigation of the relationship of its palimpsestic nature.

The term palimpsest originates from the Greek word 'palimpsestos' and it defined by several critics as a piece of parchment severally written over yet showing a superimposition within the fabric of the text, thus creating a text-in-between phenomenon. The concept according to Katin Berdint, was introduced into postcolonial discourse by linguistic critics, who described palimpsest as the act of erasing the indigenous culture by the colonial settlers to inscribe their own on the erased surface.[1] However, the process is incomplete as traces of the decimated culture interplays with the new. This analogy is used metaphorically in this study to compare the act of erasing the absurd women's image in male-authored texts in order to project what Molara-Ogundipe- Leslie calls "correction of these images of the African women in African" [2].

For the purpose of clarity, palimpsest is, the traces of the former in the latter, the old writing in the new writing; a piece of writing or any other phenomenon that has a version of the past consciously or unconsciously infused in the present attempt to create a new image. Thus, palimpsest is a method of reading that can be used metaphorically to identify or determine plausible layers of meaning in literary works. Sandra Gilbert and Susan Gubar, use the metaphorical term 'palimpsest' in the Madwoman in the Attic, to describe a work, "whose surface designs conceal or obscure deeper, less accessible (and less socially acceptable) levels of meaning" [3].

Palimpsest is often traced back to the nineteen-century writer, Thomas De Quincey. Palimpsest as a term, has been 
employed by critics in reading modernist works with different connotations and several nuances of meaning. George Bornstern describes palimpsest as, erased writings on a piece of parchment are imperfectly done, thus creating a superimposition [4]. However, the word palimpsest is now viewed beyond its original meaning; first by Romantic and Victorian writers who sized the metaphorical implications of the word. For instance, Thomas De Quincey used it as an emblem for human brain, and in Aurora Leigh, Elizabeth Barret Browning applied it to the soul. E. H. Coleridge avers that, the word was employed by S. T. Coleridge in the 1828 preface to The Wanderings of Cain to juxtapose memory. He writes that, "I have in vain tried to recover the lines from the palimpsest tablet of my memory". [5] It is through this idea of memorial impression that Quincey makes the connection between the palimpsest and the human brain. Quincey says, the human brain possesses multiple layers of old experiences which tend to interplay with new experiences.

Therefore, this study focuses on reading Adichie's Purple Hibiscus through the lens of palimpsest, interpretation is given both at the surface level and submerged level of meanings. At the submerged level of meaning, it reveals and encompasses more subtle obscure layers of meaning. While a palimpsestic reading at the literal level, entails the overwriting or rewriting upon an erased surface. The term female identity as used in this work is restricted to mean projected images of women based on intellect, emotion, experience, behavior and attitudes. By undertaking to do a palimpsestic reading of Purple Hibiscus, this paper seeks to critically analyze the underlying meanings of Adichie's projected submissive and subservient female characters and unravel the bold message Adichie advocates in the novel.

\section{Discussion}

\subsection{The Novel}

With the explanation enumerated above, we come to the next phase of this study: Palimpsestic reading of Purple Hibiscus. Adichie's Purple Hibiscus records the experiences of women mainly in the modern setting and slightly in the traditional societies. Like some third generation writers Adichie deals distinctively with the growth of her protagonist. As, kambili, the protagonist matures, she progresses from ignorance to cognition, comprehends the true nature of her socio-cultural milieu in which she has to survive as an individual and develops a model of coping with situations. Kambili's development is both physical and psychological; each stage corresponds to her environment in the novel.

Purple Hibiscus begins in a high tensed state, and this tension runs through the fabric of the text glaringly and hauntingly gripping. The novel is realized though series of flashbacks, which traces the growth, process of the narrative persona Kambili and her brother Jaja. A development, which designates their struggle to create identities beyond the stiffened and suffocating world, their Calvinistic father has created for them. The entire narrative is relayed through
Kambili Achike, a fifteen-year old school girl. The novel is not linear narrative. It is segmented into four parts, and it goes back and forth around 'Palm Sunday', but the beginning is actually before 'Palm Sunday'.

The narrative unravels the inter-women pattern of religion, politics and the destructive effects of phallocentrism. It is both a feminist appropriation and a critical presentation of political oddity in Nigeria. The characters of Kambili and Beatrice embody the psychological destructive effects of patriarchy, and reflect of the imposed identity construct of phallocentrism Through this, Adichie stresses violence against the Nigerian woman starts from the home front. The text does not only bring to limelight the impact the process of missionary education has had on men who oppress their family and others who do not obey their dictates, but it also presents male literal figure who mistreat the female characters out of misogyny and out of the impulse to bully others because they are themselves bullied.

The novel is set in post - independence Nigeria. Adichie describes her setting dexterously Kambili's home is very typical of children from affluent family, yet they are psychologically empty. Kambili narrates the ordeal they had to go through in the hands of their religious Maverick father, who controls and dictates their every move: study schedules, prayer, mass, sleep, laundry and to the point that his dominance extends to barring his children from spending time with their father grandfather (his own father) whom he despises on the basis of heathenism. Eugene's overzealous attitude and fixed religious tones dwarf members of his family. Ironically, he works hard to ensure that his family lacks nothing. His houses are spacious and roomy, yet stifling and suffocating. The entire household feels the pangs of Eugene's abuse and brutality.

Despite the fact that Eugene is feared at home, he is however venerated in the community for his successful businesses, his philanthropic nature and his upright belief in truth. The newspaper he owns dares to publish the truth about the chaotic political situation in the country. He urges his editor, Ade Coker, to ensure that The Standard speaks out, yet his wife and children's voices are atrophying by the day because of the air of chauvinism around the house.

In the midst of this chaos, Kambili and Jaja go to stay with their aunt in Nsukka and they experience a different world. Despite the hardship of the family, their aunt's world is full of life, vibrancy and laughter. It is a place where children are at liberty to speak and the cultural traditions of the people are happily respected and observed; where the family Catholicism is not suffocating and despicable. Kambili, Jaja and their mother thus realize that they can no longer tolerate the violent secrets of their lives under Eugene's dictatorship.

\subsection{The Palimpsestic Identity of Kambili}

The novel, Purple Hibiscus, comments on the complex issue of female identity in African fiction. The title denotes also a similar complexity of multiple layers of meaning. Kambili, the novel's protagonist, reveals a pattern of multiple layers of identity. At the surface, we see a passive female 
character conditioned to an imposed cultural identity where she is made to believe that "women are not supposed to know anything at all" [6]. Throughout the segment of the narrative, Kambili is a blank slate of some sort, as she seems to be mostly devoid of any sense of personal opinion about the happening in her home. Unlike her paralleled character Amaka, her paternal cousin of almost the same age, who is able to argue constructively about her opinion on issues, an example is the case of choosing an Eurocentric name for her confirmation, Kambili is engrossed in a world of "because he has said it and his word is true" [6] she narrates

I would sit with my knees pressed together next to Jaja, trying to keep my face blank, to keep the pride from showing because papa said modesty was very important [6].

Initially, the main passion of Kambili's life is to please her father, whom she idolizes to the point of senselessness. Eugene's religious indoctrination stifles every sense of rationality in her. For instance, when Eugene breaks Beatrice's (her mother) figurines a symbol of comfort to Beatrice's many woes, Kambili retorts.

I meant to say I'm sorry Papa broke your figurines but the words that came out were; I'm sorry your figurines broke Mama" [6].

Of course referring to the former, meant discrediting the god-like Eugene, whose action she views as immaculate. Due to the absence of any strong sense of personality, Kambili goes through a series of traumatic experiences that leads to her developing an identity based on imitation and docility; a kind of inter-textual palimpsest. Her identity here, reminds us of Okonkwo's wives in Achebe's Things fall Apart [7]. She narrates:

Papa poured the yellow juice for everyone I reached out quickly for my glass and took a sip. It tasted watery, I wanted to seem eager, "it's very good, Papa" I said.... "Yes, yes" it tastes like fresh cashew", mama said "Just like white wine" mama added, (despite that) fresh cashew tasted nothing like white wine (as observed by Kambili however, Kambili imitates her mother) "yes". [6 emphasis mine].

The visible layer of Kambili's identity at this point reveals a literal palimpsest that is, an identity that reminds us of the uncritical Bamu, in Joyce carry's Master Johnson [8]. Everything offered by Eugene, her father, is to be accepted hook line and sinker. She lacks Amaka's spirit of constructive criticism, who faced with similar situation handles it differently. Amaka asks Eugene,

"Does your factory make this" ..... it's a little too sweet. It would be nice if you reduce the sugar in it. Amaka's tone was polite and normal as everyday conversation with an older person [6]

Unlike Amaka, Kambili's constricted identity finds no fault in anything sanctioned by Eugene, her father, her reaction to Amaka's boldness and spirited personality reveals more about Kambili's timidity. She narrates:

I was not sure if Papa nodded or if his head simply moved as he chewed. Another knot formed in my throat, and I could not get a mouthful of rice down. I knocked my glass over as I reached for it.... [6].
The underlying reality here implies that in an oppressive system, it is not only the oppressed who is a victim, but the oppressor also loses. Eugene stifles every rationality in Kambili and other members of his family. Thus, they fail to offer him constructive criticism that could have helped him improve his various factory products.

The development of Kambili's identity is fragmented; her relationship within her home not only involves acting and imitation but also transports her into a sphere of social isolation. Eugene's harsh disciplinary measures constricted Kambili's tongue from holding normal conversation. Okuyade Ogaga observes that "she struggle within herself to hold a normal conversation, a struggle which usually terminates in a stutter, making her classmate observe her with familiarity laced with contempt" [9]. Due to her inability to make her classmates in school, she is isolated and labeled a "backyard snob" [6]. Thus symbolizing a conquered victim. Dube Musa opines that, Eugene represents a colonial conquered mind [10]. However, I argue that beyond the relic of colonial conquest, Eugene is a symbol of African patriarchy, who believes that women and children should be controlled.

The backyard snob identity Kamibili wears in school gives a palimpsest pattern, because at the surface we see a school girl, who dashes off to her father's waiting car without the patience of exchanging pleasantries with her classmates, an attitude they view as blue-blooded arrogance. Beyond this surface and snobbish identity of Kambili is the submerged pattern of a remote-controlled life, a kind of robot human controlled by the phallocentric dictator-Eugene. Even in his absence his malevolent present still dominates. Kambili's life is controlled and regulated by his inscribed schedule. Any breach of his commandments earns Papa's slap, as she recounts, "Once Kelvin told Papa I took a few minutes longer, and Papa slapped my left and right cheeks at the same time, so his huge palms left parallels marks on my face and ringing in my ear's" [6]. A ringing that hangs like a relic and turns her into a dopey.

Kambili's experiences at home and school become like prison experience, where one is stripped of every sense of freedom like the narrator in Charlotte Gilman's "The Yellow Wall paper" whose societal restrictions on women, drives her to a state of mental disorder (neurasthenia), and chokes her creative ability [11].

The narrative style denotes suspense, not only to the readers, but also to the characters within the text, because a reading beyond Kambili's identity layer in school reveals a metaphorical palimpsest. The question that may puzzle us is, what point does Adichie intend to make at this juncture? Why allow Kambili to add to her many woes her classmates' accusation? The reason for this intentional character portraiture is within the body of the text, which only palimpsestic reading unfolds. First at this point, Kambili herself has not realized that she struggles to conform to an ascribed identity, she has not yet found a voice to question the events that stifles her, she believes her father is right and would rather defend him than implicate him. Thus, her growth at this level does not permit her a serve of cognition that will 
enable her question the system that controls and stifles her. Her acceptance of this ascribed identity thus, endorses the fact that, true knowledge begets the freedom "to be and to do" [6]. At this point, Kambili is not ready to assert herself, because true liberation comes from within:

The formation of Kambili's identity is not in isolation her identity structure is influenced by both male and female characters around her. First, her mechanical father fails to help her realize her worth and her mother (Beatrice) is too docile to be her role model. She never stands out strong enough to protect her children. It becomes glaring that within the confines of patriarchal scripts of her home, Kambili is entrapped to domestic servitude, with an inner yearning for freedom.

For the different layer of Kambili's identity to emerge, there is need to erase the present form of her personality, which Amaka observes as abnormal like the old writing on a piece of parchment which is no longer considered valuable and, thus, erased to accommodate a new writing. Kambili's identity needs such similar restructuring and re-writing-Nsukka, thus becomes the place of erasure and rewriting. At Nsukka Aunty Ifeoma, Amaka and Father Amadi all influenced Kambili's next layer of identity. They, together, deconstruct her conscripted identity in order to rewrite a new form, not by imposing, but by enabling her to see beyond her imposed identity and offering her new negotiable possibilities. Thus, Kambili's next layer of identity formation centres on the re-education of the mind.

Aunty Ifeoma as Okuyade rightly observes serves as a symbol of the "Iconoclastic identity and demystifier of patriarchal and despotic establishments" [9]. She offers Kambili a platform to distinguish between right and wrong through her religious beliefs, for instance, her brief prayers during meals bewilder Kambili and she explains. "Nne, we have finished praying. We do not say mass in the name of the grace like your father does" [6].

Using the tale of King Jaja of Opobo, Aunty Ifeoma lectures them on defiance. "Being defiant can be a good thing sometimes.... When it is used right"[6]. Kambili utilizes her knowledge to resist her father. We see her revolt when Eugene tries to reprimand her for possessing Papa Nnukwu's painting.

Papa snatched the painting from Jaja. His hand moved swiftly, working together, the painting was gone, it already represented something lost, something I had ..... I dashed to the pieces on the floor as if to save them ...... I sank to the floor, lay on the pieces of paper. (Even when Papa shouted). Get up! I lay there, did nothing, I still did not move [6].

The above passage reveals vividly the new beginning of Kambili's self - asserted identity which Azuike describes as the female "self - discovery" [12]. Kambili, realizing that she must play a part to assert herself, is no longer passive. She defies her father's beating to cling to the relics of her grandfather which the painting symbolizes. Her unwillingness to let go implies that, she is willing to resist any attempt to lose what she has come to discover, not even the god like Eugene will come between her and her fragile freedom. Anthony Oha, concludes that Kambili is not a contributor character. "She never acted to change neither her situation nor things around her" [13]. To have clung to the thorn painting of her grandfather amidst the stinging of her father's kicks is a potent statement of her assertion of her new identity and an indication that she has transverse her limitation. At this point Kambili moved from the passive victim to an actor.

Secondly, Kambili sees Aunty Ifeoma as a woman that is self-reliant in a male dominated world. As a widow she is able to cope with difficult situations. Later when Eugene dies and Jaja is imprisoned, we see Kambili's self-assured effort to gain freedom of the male figure, give the text its African feminist outlook, which believes in dealing with an oppressive system in order to liberate both gender from the claws of oppression.

Thirdly, Aunty Ifeoma initiates Kambili into creativity. It is in her house, Kambili learns the steep of domestic business of cooking. Like Enitan in sefi Attah's Everything Good will come Kambili never had access to the kitchen. This aspect of her development is vital, since Kambili is looking for role models to transcend from being a passive female to a grown self - assured woman.

The emergence of Kambili's new identity is influenced also by father. Through father Amadi, Kambili gains a sense of discernment. She sees father Amadi's Catholicism as accommodating rather than compartmentalised. Father Amadi's frequent visits and closeness helps her develop psychologically. Commenting on father Amadi's influence on Kambili's identity formation, Okuyade opines that "she commits a cardinal sin through fraudian slip" [14] as she falls in love with father Amadi. Of course, a surface reading of this scene may justify the above conclusion. However, the meaning of this affair, further accentuates Kambili's identity as palimpsestic which according to Whalen gives a less social acceptable meaning. Kambili does not only fall in love with father Amadi, but she transcends the level of her conscripted silence to express this emotion. Her ability to voice out her feelings to him signifies her complete liberation and freedom. It denotes that Kambili has erased the old docile and passive nature to become active and capable of independent thought and life other than the one offered her by societal prescription.

\subsection{The Character of Beatrice}

The character of Beatrice is palimpsestic at two levels of meaning that is the surface meaning, which most critics have rightly observed and the submerged meaning beyond the surface interpretation of her identity. At the surface, we see a docile, passive and unthinking woman, who is contented to sheepishly walk behind her husband. She condones every form of violence meted out to her and her children. She contends only in the role of nursing herself and children back to sound health in readiness for another brutish bout from the Draculin Eugene. For example, we see how she responds to Eugene's hot water disciplinary therapy on Kambili, "She mixed salt with cold water and gently plastered the gritty mixture onto my feet [6].

At another instance, Eugene irrational bouts of violence which manifests in how beats Beatrice leaving as relics several miscarriages and the purple color of the skin around her eyes. X-raying the character of Beatrice reveals the 
incessant gender-based violence women are exposed to. Margaret Fafa Nutsukpo, opines that replete in Adichie's Purple Hibiscus, is a manifestation of "gender-based violence in the form of domestic violence"[15]. She further reiterates that, in African Society, "the domination of women is the most fundamental form of female subjugation".[15] In some African clime, wives battery (physical and emotional) tends to be adjudged as a norm. This is largely due to cultural influences for, the patriarchal culture, inherent in the African society, encourages prejudices against women, and accepts the battery of wives and children by husbands as a process of enshrining discipline. Hence, domestic violence becomes a regular feature in many African homes, this is graphically depicted in Adichie Purple Hibiscus.

Despite all the different shades of domestic violence, Beatrice reacts to Eugene's brutal violence stoically. Tifanny Astrick submits that, "oppressions draw its strength from the submissive of its victims who accept their image and get paralyzed by the sense of helplessness." [16] In the face of violence, Beatrice remains the selfless, enduring woman. She believes that tradition and culture expect this disposition, which will in turn preserve her marriage and a home for her children, as her rhetorical questions to her sister-in-law, Aunty Ifeoma reveals: Where do I go if I leave Eugene's house. Tell me, where will I go? Do you know how many mothers pushed their daughters at him? How many of them asked him to impregnate them, even, and not to bother paying a bride price? [6]. For the sake of her marriage and children, Beatrice bears Eugene's ruthlessness. Adichie's depiction of Beatrice at the surface level of meaning accentuate the argument that the worse form of oppression, is that which is self-abnegated, and self-induced. Beatrice hardly speaks; when she does at all, it is with timidity which culminates into whispering and monosyllables Pauline A. Uwakweh writes that:

Silencing comprises an imposed restriction on women's social being, thinking and expression that are religiously or culturally sanctioned. As a patriarchal weapon of control, it is used by the dominate male structure on the subordinate or mutual female structure [17].

Looking at Beatrice's magnified silence, a reader is tempted to see her as an illustration of "old wives in new tales", that is, she embodies an identity which is synonymous to the timid, passive and docile female character in male authored texts. But of course, as earlier mentioned, such identity resemblance only depicts a palimpsest pattern which is capable of interfering with a writer's intention. A reader might wave off such characters, as a repetition and thus blur the underlying significance of such an identity, beyond the surface passivity of Beatrice Achike's identity, we meet a female character who lives on in our imagination long after reading the text. It is thus the interpretation of the layer of identity that ignites this effect.

First, we ask, what is Adichie's intention of creating such a female character, who tolerates, endures and accommodates Eugene's excesses? Beatrice sees her husband as a product of colonialism which embodies all forms of pervasion and distortion in African society. A character whose growing up experiences as he shares with his daughter Kambili, turns into a psychopath. Beatrice, rather than react harshly towards him, devices a means to endure, a potent quality of the African woman. She is not bothered by Aunty Ifeoma's lectures that "Sometimes life begins when marriage ends" [6].

However, events take different turn and subsequently, sows the seed of rebellion in Beatrice. Adichie does not expect us to dismiss the character of Beatrice as the docile, murderous wife, who seems to tolerate Eugene's brutality as a traditional and religious obligation. She uses language to codify her identity, which gives it a palimpsestic pattern, and only an unlayering of such identity will produce textual meaning.

Beatrice initially believes that her marriage, irrespective of the domestic quagmire, gives her and her children social security. Thus, like the womanish, she is able to endure and tolerate the oppression she suffers for the sake of her children. Beatrice reveals an identity pattern that embodies the traditional African woman, sophisticated and content with the economic security her husband guarantees. This portraiture however, does not last, when she almost lost the very reason that keeps her in Eugene's choking world-her children, "things started to fall apart" [6]. Kambili narrates:

He started to kick me .... Kicking, kicking. Kicking. Perhaps, it was a belt now because the metal buckle seemed too heavy. Because I could hear a swoosh in the air. A low voice was saying "please, biko, please" ....... I closed my eyes and slipped away into quite [6].

Eugene's lunatic attack on his daughter leaves Kambili with a "broken rib" and "internal bleeding" [6]. This becomes the "final blow that broke the camel's back". In the frenzy that ensured when Eugene embarks on his cleansing act upon his daughter, Beatrice, for the first time, finds her voice. First, it was timidly low and pleading, "please, biko, please" [6]. Aunty Ifeoma's proverbial statement that "when a house is on fire, you run out before the roof collapses on your head" [6], becomes a spring board that pushed Beatrice outside her entrapped identity to look for a solution. Thus, for the first time also, she does not argue with Aunty Ifeoma, it was after this incident that Beatrice discovers like someone in an illusory world, that there is need to liberate herself and her children from the burning fire set by her husband's sinking philosophy. Beatrice, like Kambili, reveals a palimpsestic pattern, whose several layers of personality develop gradually and interestingly. She steps out of her docile state, breaks the patriarchal social structure and demystifies traditional images of the African woman.

We see a female character whose surface gives a picture of innocence, harmlessness and compassion, gradually degrading to a level of a murderer. She successfully schemes to poison her husband with Sisi her maid like the secular song writer says; "you make a good girl go crazy, if you don't treat her like a lady", Eugene's violence against Kambili, shakes Beatrice free from the passive role of a house wife. Already conditioned to violence, she thinks of violence as the only option to assert her identity and create space for her children. It is this aspect that gives the novel its radical feminist outlook. The concern is, must murder be the only option available to the oppressed female victim? Must she assert herself by killing the oppressor? No matter the level of her torture in the hands of Eugene, resorting to murder is not justifiable, this is 
the problematic stance of the novel, and it often leads to a misinterpretation of the feminist quest. The poisoning of Eugene which leads to his death might be seen as an effort by the oppressed to destroy the oppressive system, however, we strongly argue that there were other options which Beatrice could have resorted to, rather than committing a crime, to negotiate her identity.

A surface reading of the above event is about to lead to a misinterpretation of female quest for an asserted identity and label the author an advocate of men's annihilation. Thus, we looked beyond the surface writing to resolve this dilemma. Beatrice's psychological condition deteriorates, after she kills her husband, her option further throws her into marginality as she becomes insane. Also, her desire to liberate her children from their entrapment, to give them freedom fails, as Jaja her son is imprisoned. Thus, like the aftermath of a volcanic eruption, whose molten magma is eager to liberate itself from confinement, Beatrice's effort further compounds her problems. The consequences of her action include ironically, the imprisonment of her son and herself induce insanity. These consequences go a long way in proving that the author does not advocate for a matriarchal order in place of patriarchy. Thilagavathi, P. writes that "the linguistic acumen displayed by the author [in the novel], looks into how women are underestimated, downgraded, second classed and rather looked down upon by their men counterparts and how women are rising to the occasion to take on men's challenge on this [18]. To this end, Adichie exemplifies this on a number of occasions in Purple Hibiscus.

Adichie does not sanction Beatrice's approach to assert herself, thus she does not equip her with the sanity she needs to fully enjoy the dividend of the quest. Ironically, she is still entrapped, and must suffer insanity as a purgatory device, until her son gains his freedom. It is after Jaja's freedom, that Kambili says "the new rains will come down soon" [6]. This implies that true liberation within the African context is the liberation of all gender from any form of oppression.

\section{Conclusion}

Finally, through the various characters in the novel, Adichie advocates for a society where individuals are not restricted due to their gender. Kambili for instance, is influence to develop several identity layers. Azuike opines that most African feminist texts are "couched in deep ironies which allow the readers to engage in manifold interpretations of such texts" [8]. And the above analysis reveals that multiplicity of interpretation is possible in the text

The split personality of Beatrice leads to her multi-layered identity, a kind of palimpsest. Firstly, at the surface, she is docile and passive wife of Eugene Achike, who offers no plausible model to her daughter; second, she is portrayed as the negative outcome of a prolonged oppressive system as she turns into a social deviate and take a radical stand.

Adichie allows Beatrice's insanity as a proof that as an African feminist, the fight for the right of woman need not diminish the rights of men because the planet is large enough for everybody according to an Igbo proverbs ("Egbe bere ugo bere, nkesi ibe ya bellie, nku kwaa ya". Let the kite perch and let the eagle perch, but the one that hinders the other from perching loses it wings). There is no need to sidetrack the argument for women's self-assertion by implying that it takes away the rights of men. This stance the study advocates for, through the palimpsestic reading of the characters of Kambili (the narrator) and Beatrice in Purple Hibiscus.

\section{References}

[1] Berndt, Katrin: Female Identity in Contemporary Zimbabwean Fiction. Germany, Pia Theilman \& Eckhard Breitinger, 2005.

[2] Ogundipe- Leslie, Molara. Re-creating Ourselves: African Women and Critical Transformation. Trenton, NJ: African World Press, 1994. p. 5.

[3] Gilbert, Sandra M., and Susan Gubar. The Madwoman in the Attic: The Woman Writer and the Nineteenth-Century Literary Imagination. Second Edition. New Haven: Yale University Press. 1979, 2000.

[4] Bornstein, G. "Introduction" Palimpsest: Editorial Theory in the Humanities. eds. George Bornstein and Ralph G. William. www.pressumich.edu/titledetailsdesc.do. Accessed 13/03/2020

[5] Coleridge, E. H. "Christabel, Hypertext, Palimpsest". www.erudit.org/revue/RON/1998/v/nio. Accessed 13/03/2020

[6] Adichie, N. Chimamanda. Purple Hibiscus. Lagos: Farafina, 2004. p. 5, 13, 16, 10, 51, 53, 87, 95, 98, 144, 210, 302.

[7] Achebe, Chinua. Things Fall Apart. London: Heinmann, 1958.

[8] Cary, Joyce. Mister Johnson. New York: Directions, 1989 edition. Print.

[9] Okuyade, Ogaga. "Changing Borders Creating Voices: Silence as Character in Chimamanda Adichie's Purple Hibiscus". The Journal of Pan African Studies, 2.9. (2009): p. 247 http://jpanafrican.com/docs/vol2no9/2.9_Changing_Borders_a nd_Creating_V oices.pdf. Web.

[10] Dube, Musa. Purple Hibiscus: A Postcolonial Feminist Reading. Missionalia. 46. 10.7832/46-2-311. 2019.

[11] Gilman, Charlotte. "The Yellow Wallpaper". www.gutenberg.org/etext/TheYellow Wallpaper. Retrieved $13 / 03 / 2020$.

[12] Azuike, Maureen A. "Women's struggles and independence in Adichie's Purple Hibiscus and Half of a Yellow Sun" African Research Review An international multi-disciplinary Journal, 3. 4 (2009): p. 82 http:/ajol.info/index.php/afrrev/article/ Web.

[13] Oha C. Anthony. "Beyond the odds of the Red Hibiscus: A critical reading of Chimamanda Adichie's Purple Hibiscus". The Journal of Pan African Studies. 1.9. (2007): p. 199.

[14] Okuyade, Ogaga "Trying to Survive: Growth and transformation in African Female Narratives". Califonia Linguistic Notes. Xxxvi. L, (2010): 1-33.

[15] Nutsukpo, Margaret. F. "Domestic Violence in Chimamanda Ngozi Adichie's Purple Hibiscus" International Journal of Arts and Humanities (IJAH) Ethiopia. Vol. 6 (3), S/No 22, July, 2017: 118-126. 
[16] Astrick, Tifanny. Patriarchal Oppression and Women Empowerment in Chimamanda Ngozi Adichie's Purple Hibiscus. Vivid Journal of Language and Literature. 7. 45. 10.25077/vj.7.2.45-50.2018.

[17] Uwakweh Ada Pauline. Debunking Patriarchy: The Liberation Quality of Voicing in Tisitsi Dangarembga's Nervous
Conditions". Research in African Literatures 26: 1 1995: 75-84.

[18] Thilagavathi, R. P. The use of Language in Chimamanda Adichie's Purple Hibiscus. SMART MOVES JOURNAL IJELLH, 7 (6), 11. 2019. 